Angew Chem Int Ed Engl. 2017 March 20; 56(13): 3630-3634. doi:10.1002/anie.201611407.

\title{
Palladium-Catalyzed Pyrazole-Directed $\mathrm{sp}^{3} \mathrm{C}-\mathrm{H}$ Bond Arylation for the Synthesis of $\beta$-Phenethylamines
}

\author{
Nurbey Gulia and \\ Department of Chemistry, University of Houston, Houston, TX 77204-5003 (USA) \\ Department of Chemistry, University of Wrocław, 14 F. Joliot-Curie, 50-383 Wrocław (Poland) \\ Olafs Daugulis \\ Department of Chemistry, University of Houston, Houston, TX 77204-5003 (USA)
}

\begin{abstract}
We have developed a method for palladium-catalyzed, pyrazole-directed $\mathrm{sp}^{3} \mathrm{C}-\mathrm{H}$ bond arylation by aryl iodides. The reaction employs a $\mathrm{Pd}(\mathrm{OAc})_{2}$ catalyst at 5-10 mol\% loading and silver(I) oxide as a halide-removal agent, and it proceeds in acetic acid or acetic acid/ hexafluoroisopropanol solvent. Ozonolysis of the pyrazole moiety affords pharmaceutically important $\beta$-phenethylamines.
\end{abstract}

\section{Keywords}

arenes; $\mathrm{C}-\mathrm{C}$ coupling; $\mathrm{C}-\mathrm{H}$ activation; homogeneous catalysis; palladium

In recent years, carbon-hydrogen bond functionalization methods have developed from an organometallic curiosity into a useful approach for the synthesis of complex natural products and drug-like molecules. ${ }^{[1,2]}$ The use of $\mathrm{C}-\mathrm{H}$ bonds as transformable functional groups is advantageous since these moieties are typically the most abundant functionalities in organic molecules. Direct conversion of these bonds into the desired functionality results in economic and ecological benefits since less chemical waste is generated as a result of shortened synthetic pathways.

During the last decade, many examples of directed intermolecular $\mathrm{sp}^{3} \mathrm{C}-\mathrm{H}$ bond functionalization reactions have been disclosed. ${ }^{[3,4]}$ However, several key issues are still not solved. Perhaps the most challenging among them is control of the site selectivity of the C$\mathrm{H}$ functionalization. Directing-group strategies allow functionalization at the 4-position from the coordinating heteroatom owing to a preference for five-membered metallacycle formation (Scheme 1A). This results in $\gamma$-functionalization of amine and $\beta$-functionalization of carboxylic acid derivatives. ${ }^{[3,4]}$ Functionalization of other positions is possible if the 4 -

Correspondence to: Olafs Daugulis.

Supporting information and the ORCID identification number(s) for the author(s) of this article can be found under: http://dx.doi.org/ 10.1002/anie.201611407.

Conflict of interest

The authors declare no conflict of interest. 
position relative to the coordinating heteroatom is blocked or hindered, resulting in a limited reaction scope. ${ }^{[5]}$ Another strategy employs the higher reactivity of methyl relative to methylene groups in non-directed $\mathrm{C}-\mathrm{H}$ oxygenation, as shown by the Sanford group. ${ }^{[6]}$ Dong and co-workers have reported several examples of the $\beta$-oxygenation of amine and alcohol derivatives. ${ }^{[7 a, b]}$

There have been three reported $\beta$-arylations of aliphatic amine derivatives (Scheme $1 \mathrm{~B}, \mathrm{C}) .{ }^{[7 \mathrm{c}, \mathrm{d}, \mathrm{e}]}$ While conceptually important, these methods are limited by the requirement for quaternary centers next to a nitrogen atom or strong base in the deprotonation step. Additionally, relatively few auxiliaries besides bidentate monoanionic directing groups are capable of promoting functionalization at unactivated methylene positions. ${ }^{[4 c, d, e, 7 \mathrm{~d}, 8]}$ Among those, the perfluorinated anilines reported by Yu and co-workers, are notable. ${ }^{[4 \mathrm{~d}, \mathrm{e}, 8 \mathrm{~b}]} \mathrm{Clearly}$, additional methods are required to achieve convenient and regioselective functionalization of unactivated $\mathrm{sp}^{3} \mathrm{C}-\mathrm{H}$ bonds. Especially interesting is the selective and general $\beta$-arylation of aliphatic amines, since $\beta$-phenethylamines are key structural components in important medicines and natural products. ${ }^{[9]}$ We report herein a method for palladium-catalyzed pyrazole-directed $\mathrm{sp}^{3} \mathrm{C}-\mathrm{H}$ bond arylation by aryl iodides. The reaction tolerates a wide range of functional groups and allows removal of the directing group to reveal the pharmaceutically important $\beta$-phenethylamine functionality. Furthermore, this is the first example of using a pyrazole moiety as a transformable directing group in $\mathrm{sp}^{3} \mathrm{C}-\mathrm{H}$ functionalization.

Arylpyrazoles can be cyclopalladated, which shows that pyrazole is an efficient directing group. ${ }^{[10]}$ Furthermore, the pyrazole moiety has been extensively used as a directing group for palladium- and ruthenium-catalyzed $\mathrm{sp}^{2} \mathrm{C}-\mathrm{H}$ bond arylation. ${ }^{[11]}$ There are only a few isolated reports of pyrazole directing groups in palladium- and iridium-catalyzed $\mathrm{sp}^{3} \mathrm{C}-\mathrm{H}$ bond functionalization. ${ }^{[12]}$ In 2006, we showed that 1-phenyl-pyrazole can be ortho-arylated under the conditions that are effective for 2-phenylpyridine functionalization. ${ }^{[11 a]}$ Since 2ethylpyridine is arylated under those conditions, it seemed reasonable that 1-ethylpyrazole and other alkylpyrazoles could be reactive as well.

Optimization was carried out with respect to the silver source and additives (Table 1). A reasonable arylation rate was observed at $130^{\circ} \mathrm{C}$ in acetic acid, while reactions in other solvents, such as $\mathrm{H}_{2} \mathrm{O}, \mathrm{DMF}$, acetonitrile, $t$-butanol, dioxane, dichloroethane, and cyclooctane afforded very low conversions. Entry 1 shows that arylation in acetic acid by using silver acetate as the base and halide-removing agent gives product in only $18 \%$ yield. Addition of sodium trifluoroacetate improved the yield to $48 \%$ (entry 2). Even higher yields are obtained if sodium triflate is employed as an additive (entry 3). Lithium triflate as an additive gave the same yield as the sodium salt, thus showing that the anion is important in arylation (entry 4). The use of silver trifluoroacetate in combination with lithium triflate further improved the yield to $79 \%$ (entry 5). Attempts to replace the expensive silver trifluoroacetate with a cheaper silver source were fruitful, as shown in entries 6 and 7. The use of a silver acetate mixture with trifluoroacetic acid gave a 75\% yield of arylation product (entry 6). It is possible to replace $\mathrm{AgOAc}$ with $\mathrm{Ag}_{2} \mathrm{O}$, which is one of the cheapest commercially available silver salts (entry 7). An acetic acid/hexafluoroisopropanol solvent mixture gives the same yield as the reaction run in pure acetic acid (entry 8); however, for 
electron-poor aryl iodides, this is the best solvent combination. Finally, addition of LiOAc slightly increases the yield, allows the reaction to occur at $105^{\circ} \mathrm{C}$, and gives more reproducible reaction yields at larger scale (entry 9). No reaction was observed if $\mathrm{Pd}(\mathrm{OAc})_{2}$ was omitted. The use of bases other than silver salts resulted in very low conversions.

Other directing groups were tested under the optimized conditions (Scheme 2). Unsubstituted ethylpyrazole and methyl-substituted compounds gave arylation products in yields that are slightly lower than those for 1-ethyl-3,5-dimethylpyrazole (2-1 to 2-3). Pyrazoles possessing aryl substituents are also reactive, and products were obtained in fair to good yields (2-4, 2-5). Ethyltriazoles were not arylated under the optimized conditions (2-6 and 2-7). This result demonstrates the higher efficiency of bidentate coordination in $\mathrm{C}-\mathrm{H}$ functionalization, since triazoles possessing an additional chelating group are efficient auxiliaries for $\mathrm{C}-\mathrm{H}$ functionalization. ${ }^{[4 \mathrm{j}, 13]}$ Overall, 3,5-dimethylpyrazole is the optimal auxiliary for the arylation, based both on reactivity and cost.

The reaction scope with respect to the aryl iodides is presented in Table 2. The reactions were successful with both electron-rich (entries 1-6) and electron-poor (entries 8-13) aryl iodides. Various functionalities, such as methoxy (entries 4, 6), chloro (entries 7,8), trifluoromethyl (entry 9), ester (entry 10), ketone (entry 11), trifuoromethoxy (entry 12), and fluoro (entry 13) groups are tolerated. The reaction can be scaled to $10 \mathrm{mmol}$ without any loss in yield (entry 7). Typically, the arylations with electron-poor aryl iodides were slower than those with electron-rich substrates. This trend is also often observed for $\mathrm{C}-\mathrm{H}$ functionalization when employing bidentate auxiliaries. ${ }^{[3 \mathrm{~b}]}$

The reaction scope with respect to the alkyl on the pyrazoles is presented in Table 3 . The isopropyl derivative was arylated in $50 \%$ yield (entry 1 ), while the $s$-butyl-substituted compound reacted at the methyl group to afford product in $60 \%$ yield (entry 2). Larger alkyl groups are tolerated as well (entries 3 and 4). Phenethyl and phenyl-propylpyrazoles afforded the products in 53 and 56\% yields (entries 5 and 6). A compound possessing an ester substitution was arylated in $55 \%$ yield (entry 7 ).

Directed functionalization of secondary, unactivated (not benzylic or a to heteroatom) $\mathrm{sp}^{3} \mathrm{C}$ $-\mathrm{H}$ bonds is relatively rare. Besides bidentate monoanionic auxiliaries, which can promote the activation of even some tertiary positions, ${ }^{[14]}$ few directing groups can effect methylene $\mathrm{C}-\mathrm{H}$ bond functionalization. We were pleased to discover that dimethylpyrazole directs the arylation of some secondary and even tertiary $\mathrm{C}-\mathrm{H}$ bonds (Scheme 3). Propylpyrazole gave a mixture of products resulting from arylation of both the methylene and methyl groups (3-2 and 3-3). Pyrazolyladamantane 3-4 was arylated in 53\% yield to give product 3-5.

Compound 3-6, which contains the dimethyladamantane moiety present in memantine, ${ }^{[15]}$ reacted well to give arylation product 3-7 in $45 \%$ yield. Interestingly, 2-adamantylsubstituted pyrazole 3-8 was reactive and afforded three compounds. The major one was the $\gamma$-functionalizaton product 3-9, which was isolated in $41 \%$ yield. Monoarylation at the tertiary $\beta$-position was also observed, giving 3-10 in 30\% yield. Diarylation product 3-11 was isolated in $16 \%$ yield. This is a rare example of a directed arylation of a non-activated tertiary $\mathrm{sp}^{3} \mathrm{C}-\mathrm{H}$ bond. 
The advantage of pyrazole directing groups lies in the possibility of their removal to afford useful $\beta$-arylamines (Scheme 4). Ozonolysis of arylated pyrazole ${ }^{[16]}$ (Table 2, entry 7) affords phenethylamine 4-1 in 55\% yield. If reductive workup is omitted, 54\% of the $\mathrm{N}$ nitroso derivative 4-2 is obtained.

In conclusion, we have shown that pyrazoles can direct the palladium-catalyzed functionalization of unactivated $\mathrm{sp}^{3} \mathrm{C}-\mathrm{H}$ bonds. The reaction employs $\mathrm{Pd}(\mathrm{OAc})_{2}$ as the catalyst at 5-10 mol\% loading and silver(I) oxide as a halide-removal agent and base precursor, and it proceeds in either acetic acid or acetic acid/hexafluoroisopropanol solvent. Ozonolysis of the pyrazole moiety affords pharmaceutically significant $\beta$-phenethylamines. Since $N$-substituted pyrazoles can be obtained from alkylamines, ${ }^{[17]}$ their arylation can be thought of as $\beta$-funtionalization of aliphatic amines, which are revealed after ozonolysis. The chemistry described here is a rare example of formal amine $\mathrm{sp}^{3} \mathrm{C}-\mathrm{H}$ bond $\beta$-arylation.

\section{Supplementary Material}

Refer to Web version on PubMed Central for supplementary material.

\section{Acknowledgments}

We thank the Welch Foundation (Chair E-0044) and NIGMS (Grant No. R01GM077635) for supporting this research.

\section{References}

1. Reviews:a) Colby DA, Bergman RG, Ellman JA. Chem Rev. 2010; 110:624. [PubMed: 19438203] b) Ackermann L. Chem Rev. 2011; 111:1315. [PubMed: 21391562] c) Engle KM, Mei TS, Wang X, Yu JQ. Angew Chem Int Ed. 2011; 50:1478.Angew Chem. 2011; 123:1514.d) Topczewski JJ, Sanford MS. Chem Sci. 2015; 6:70. [PubMed: 25544882] e) Gao K, Yoshikai N. Acc Chem Res. 2014; 47:1208. [PubMed: 24576170] f) Daugulis O, Roane J, Tran LD. Acc Chem Res. 2015; 48:1053. [PubMed: 25756616] g) Hartwig JF. J Am Chem Soc. 2016; 138:2. [PubMed: 26566092]

2. a) Feng Y, Chen G. Angew Chem Int Ed. 2010; 49:958.Angew Chem. 2010; 122:970.b) Gutekunst WR, Baran PS. J Am Chem Soc. 2011; 133:19076. [PubMed: 22066860] c) Gutekunst WR, Baran PS. J Org Chem. 2014; 79:2430. [PubMed: 24548142] d) Ting CP, Maimone TJ. Angew Chem Int Ed. 2014; 53:3115.Angew Chem. 2014; 126:3179.e) Dailler D, Danoun G, Baudoin O. Angew Chem Int Ed. 2015; 54:4919.Angew Chem. 2015; 127:5001.f) Chapman LM, Beck JC, Wu L, Reisman SE. J Am Chem Soc. 2016; 138:9803. [PubMed: 27452034] g) Dailler D, Danoun G, Ourri B, Baudoin O. Chem Eur J. 2015; 21:9370. [PubMed: 26031222]

3. a) Zaitsev VG, Shabashov D, Daugulis O. J Am Chem Soc. 2005; 127:13154. [PubMed: 16173737] b) Shabashov D, Daugulis O. J Am Chem Soc. 2010; 132:3965. [PubMed: 20175511] c) Tran LD, Roane J, Daugulis O. Angew Chem Int Ed. 2013; 52:6043.Angew Chem. 2013; 125:6159.

4. a) Baudoin O. Chem Soc Rev. 2011; 40:4902. [PubMed: 21505712] b) Engle KM, Mei TS, Wasa M, Yu JQ. Acc Chem Res. 2012; 45:788. [PubMed: 22166158] c) Topczewski JT, Cabrera PJ, Saper NI, Sanford MS. Nature. 2016; 531:220. [PubMed: 26886789] d) Wasa M, Chan KS, Zhang XG, He J, Miura M, Yu JQ. J Am Chem Soc. 2012; 134:18570. [PubMed: 23116159] e) Chan KSL, Fu HY, Yu JQ. J Am Chem Soc. 2015; 137:2042. [PubMed: 25581489] f) Xu Y, Young MC, Wang C, Magness DM, Dong G. Angew Chem Int Ed. 2016; 55:9084.Angew Chem. 2016; 128:9230.g) Zhang Q, Yin XS, Chen K, Zhang SQ, Shi BF. J Am Chem Soc. 2015; 137:8219. [PubMed: 26067591] h) Kim J, Sim M, Kim N, Hong S. Chem Sci. 2015; 6:3611.i) Gu Q, Al Mamari HH, Graczyk K, Diers E, Ackermann L. Angew Chem Int Ed. 2014; 53:3868.Angew Chem. 2014; 126:3949.j) Ye X, He Z, Ahmed T, Weise K, Akhmedov NG, Petersen JL, Shi X. Chem Sci. 2013; 4:3712.k) Rodríguez N, Romero-Revilla JA, Fernández-Ibáñez MÁ, Carretero JC. Chem Sci. 2013; 
4:175.1) Hasegawa N, Charra V, Inoue S, Fukumoto Y, Chatani N. J Am Chem Soc. 2011; 133:8070. [PubMed: 21542614]

5. a) Li S, Zhu RY, Xiao KJ, Yu JQ. Angew Chem Int Ed. 2016; 55:4317.Angew Chem. 2016; 128:4389.b) Reddy BVS, Reddy LR, Corey EJ. Org Lett. 2006; 8:3391. [PubMed: 16836413] c) He G, Zhang SY, Nack WA, Pearson R, Rabb-Lynch J, Chen G. Org Lett. 2014; 16:6488. [PubMed: 25487778] A notable exception- $\delta$-functionalization by employing picolin-amide directing group:d) Xu JW, Zhang ZZ, Rao WH, Shi BF. J Am Chem Soc. 2016; 138:10750. [PubMed: 27529372]

6. Lee M, Sanford MS. J Am Chem Soc. 2015; 137:12796. [PubMed: 26439251]

7. a) Huang Z, Wang C, Dong G. Angew Chem Int Ed. 2016; 55:5299.Angew Chem. 2016; 128:5385.b) Xu Y, Yan G, Ren Z, Dong G. Nat Chem. 2015; 7:829. [PubMed: 26391083] c) He C, Gaunt MJ. Angew Chem Int Ed. 2015; 54:15840.Angew Chem. 2015; 127:16066.d) Millet A, Larini P, Clot E, Baudoin O. Chem Sci. 2013; 4:2241.e) Millet A, Dailler D, Larini P, Baudoin O. Angew Chem Int Ed. 2014; 53:2678.Angew Chem. 2014; 126:2716.

8. a) Desai LV, Hull KL, Sanford MS. J Am Chem Soc. 2004; 126:9542. [PubMed: 15291549] b) He J, Li S, Deng Y, Fu H, Laforteza BN, Spangler JE, Homs A, Yu JQ. Science. 2014; 343:1216. [PubMed: 24626923] c) Chen G, Shigenari T, Jain P, Zhang Z, Jin Z, He J, Li S, Mapelli C, Miller MM, Poss MA, Scola PM, Yeung KS, Yu JQ. J Am Chem Soc. 2015; 137:3338. [PubMed: 25697780]

9. a) Bentley KW. Nat Prod Rep. 1990; 7:245. [PubMed: 2216064] b) Khan MZ, Nawaz W. Biomed Pharmacother. 2016; 83:439. [PubMed: 27424325] c) Broadley KJ. Pharmacol Ther. 2010; 125:363. [PubMed: 19948186] d) Lindemann L, Hoener MC. Trends Pharmacol Sci. 2005; 26:274. [PubMed: 15860375]

10. Caygill GB, Steel PJ. J Organomet Chem. 1987; 327:115.

11. a) Shabashov D, Daugulis O. Org Lett. 2005; 7:3657. [PubMed: 16092843] b) Ackermann L, Althammer A, Born R. Tetrahedron. 2008; 64:6115.c) Ackermann L, Althammer A, Born R. Angew Chem Int Ed. 2006; 45:2619.Angew Chem. 2006; 118:2681.d) Hull KL, Sanford MS. J Am Chem Soc. 2007; 129:11904. [PubMed: 17845047] e) Boerth JA, Hummel JR, Ellman JA. Angew Chem Int Ed. 2016; 55:12650.Angew Chem. 2016; 128:12840.f) Hofmann N, Ackermann L. J Am Chem Soc. 2013; 135:5877. [PubMed: 23534668]

12. a) Yang W, Ye S, Fanning D, Coon T, Schmidt Y, Krenitsky P, Stamos D, Yu JQ. Angew Chem Int Ed. 2015; 54:2501.Angew Chem. 2015; 127:2531.b) Gao P, Guo W, Xue J, Zhao Y, Yuan Y, Xia Y, Shi Z. J Am Chem Soc. 2015; 137:12231. [PubMed: 26348796] c) Yuan C, Tu G, Zhao Y. Org Lett. 2017; 19:356. [PubMed: 28035822]

13. Santrač D, Cella S, Wang W, Ackermann L. Eur J Org Chem. 2016:5429. see Ref [4j].

14. a) Ren Z, Dong G. Organometallics. 2016; 35:1057.b) Hoshiya N, Takenaka K, Shuto S, Uenishi JI. Org Lett. 2016; 18:48. [PubMed: 26654827]

15. Ehret MJ, Chamberlin KW. Clin Ther. 2015; 37:1604. [PubMed: 26122885]

16. Kashima C, Hibi S, Maruyama T, Harada K, Omote Y. J Heterocycl Chem. 1987; 24:637.

17. Armstrong A, Jones LH, Knight JD, Kelsey RD. Org Lett. 2005; 7:713. [PubMed: 15704932]

Angew Chem Int Ed Engl. Author manuscript; available in PMC 2018 March 20. 
A. Typical arylation regioselectivity: amine $\gamma$-functionalization

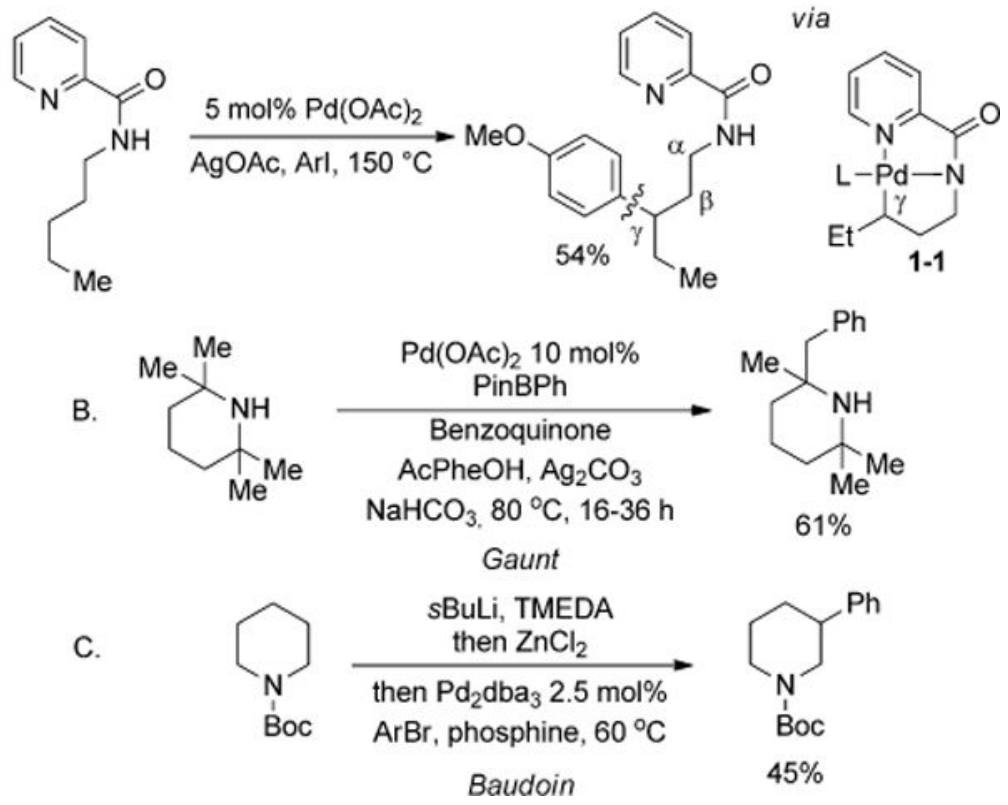

Scheme 1.

Arylation regioselectivity and amine $\beta$-functionalization. 


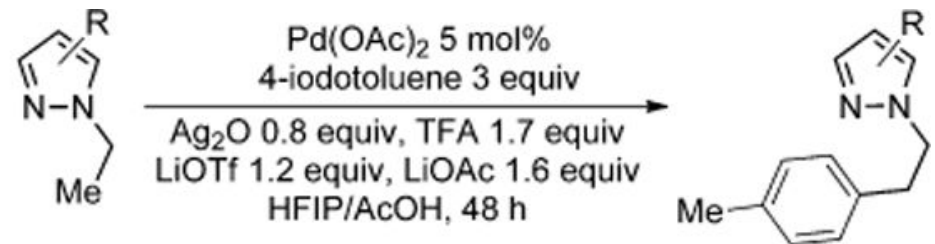<smiles>Cc1ccc(CCn2cccn2)cc1</smiles><smiles>Cc1ccc(CCn2cc(C)cn2)cc1</smiles><smiles>Cc1ccc(CCn2cc3ccccc3n2)cc1[Na]</smiles><smiles>Cc1ccc(CCn2nccc2-c2ccccc2)cc1</smiles><smiles>Cc1ccc(CCn2nc(C)c(C)c2C)cc1</smiles>

Scheme 2.

Other directing groups. 

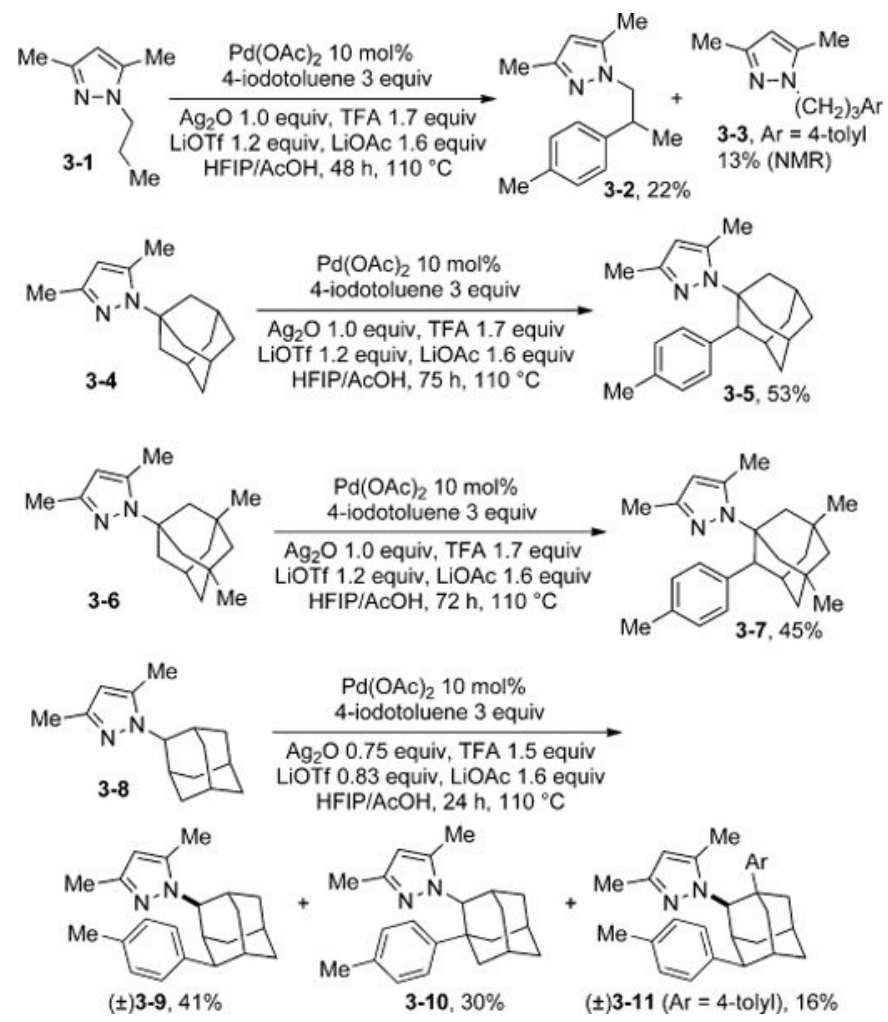

Scheme 3.

Arylation of secondary and tertiary $\mathrm{C}-\mathrm{H}$ bonds. 


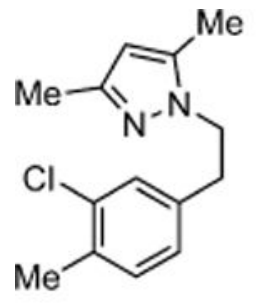

1) $\mathrm{O}_{3}, \mathrm{MeOAc} /$ pyridine<smiles>CC(=O)NCCc1ccc(C)c(Cl)c1</smiles><smiles>Cc1cc(C)n(CCc2ccc(C)c(Cl)c2)n1</smiles>
$-78^{\circ} \mathrm{C}$

2) $\mathrm{NaBH}_{4}, \mathrm{NiCl}_{2}{ }^{*} 6 \mathrm{H}_{2} \mathrm{O}$ $\mathrm{MeOH},-78^{\circ} \mathrm{C}$ to rt 4-1, $55 \%$

Scheme 4.

Directing-group removal.

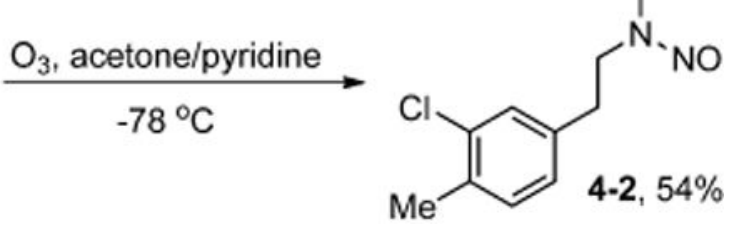




\section{Table 1}

Optimization of reaction conditions. ${ }^{[a]}$

\begin{tabular}{|c|c|c|c|}
\hline e & $\mathrm{Pd}($ & $\begin{array}{l}25 \text { mol\% } \\
\text { lotoluene } \\
\text { rce } 1.5 \text { equiv } \\
\text { tive, AcOH } \\
{ }^{\circ} \mathrm{C}, 24 \mathrm{~h}\end{array}$ & $\mathrm{~N}-\mathrm{N}$ \\
\hline Entry & Ag source & Additive(s) & Yield [\%] \\
\hline 1 & $\mathrm{AgOAc}$ & none & 18 \\
\hline 2 & $\mathrm{AgOAc}$ & $\mathrm{NaOCOCF}_{3}$ & 48 \\
\hline 3 & $\mathrm{AgOAc}$ & NaOTf & 63 \\
\hline 4 & $\mathrm{AgOAc}$ & LiOTf & 63 \\
\hline 5 & $\mathrm{AgOCOCF}_{3}$ & LiOTf & 79 \\
\hline${ }_{6}^{[b]}$ & $\mathrm{AgOAc}$ & LiOTf/TFA & 75 \\
\hline${ }_{7}^{[c]}$ & $\mathrm{Ag}_{2} \mathrm{O}$ & LiOTf/TFA & 77 \\
\hline${ }_{8}^{[d]}$ & $\mathrm{Ag}_{2} \mathrm{O}$ & LiOTf/TFA & 76 \\
\hline $9[e]$ & $\mathrm{Ag}_{2} \mathrm{O}$ & LiOTf/TFA/LiOAc & 81 \\
\hline
\end{tabular}

${ }^{[a]}$ Pyrazole $0.2 \mathrm{mmol}$, 4-iodotoluene $0.6 \mathrm{mmol}$, AcOH $0.2 \mathrm{~mL}$, additive $0.3 \mathrm{mmol}$. Yields were determined by GC analysis.

${ }^{[b]}$ Additives: LiOTf 1.2 equiv, trifluoroacetic acid 1.5 equiv.

${ }^{[c]}$ Silver oxide 0.75 equiv, additives: LiOTf 1.2 equiv, trifluoroacetic acid 1.5 equiv.

${ }^{[d]}$ Silver oxide 0.75 equiv, additives: LiOTf 1.2 equiv, trifluoroacetic acid 1.5 equiv, hexafluoropropanol/AcOH solvent $(3: 1), 120^{\circ} \mathrm{C}$.

${ }^{[e]}$ Silver oxide 0.8 equiv, additives: LiOTf 1.2 equiv, trifluoroacetic acid 1.7 equiv, LiOAc 1.6 equiv, $105^{\circ} \mathrm{C}$, yield of isolated product. $\mathrm{OTf}=-\mathrm{OSO}_{2} \mathrm{CF}_{3}, \mathrm{TFA}=\mathrm{CF}_{3} \mathrm{CO}_{2} \mathrm{H}$. 


\section{Table 2}

Reaction scope with respect to the aryl iodides. ${ }^{[a]}$

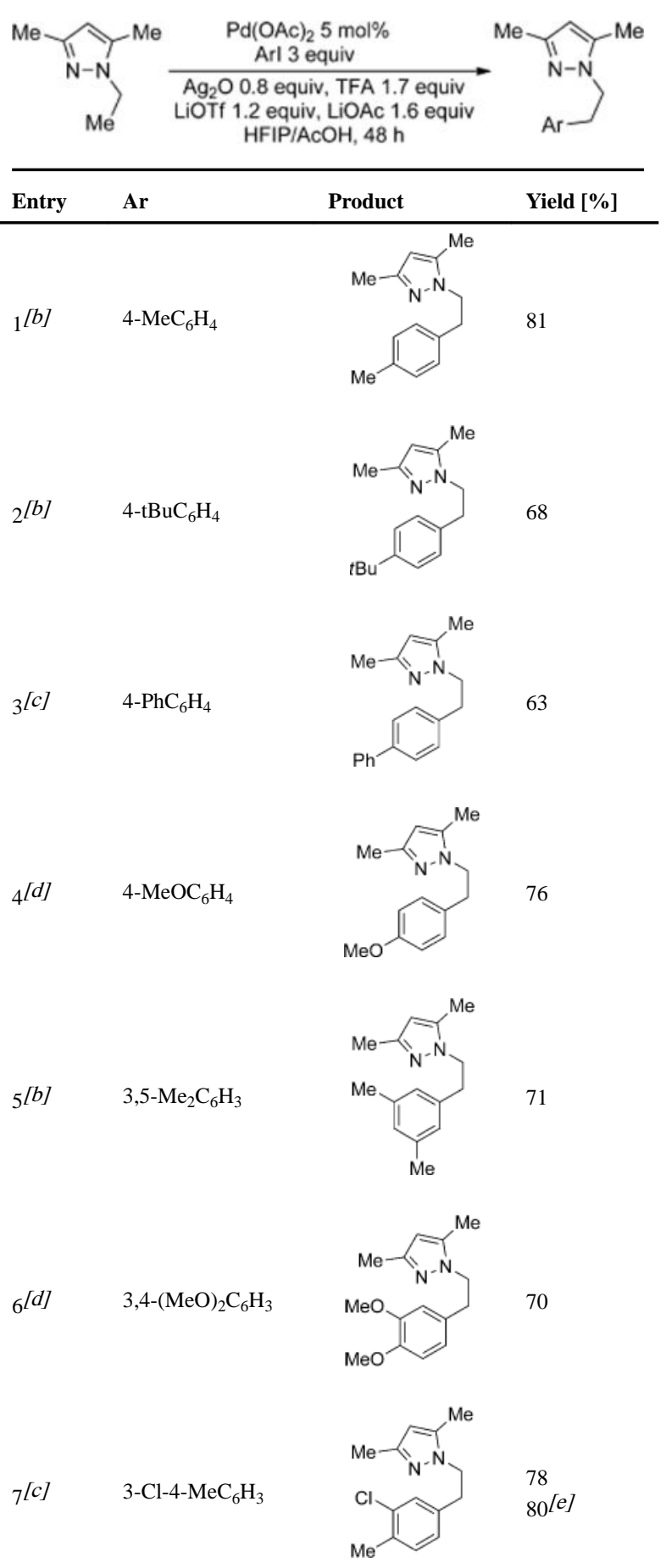




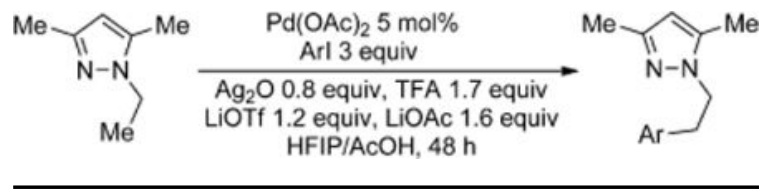

\begin{tabular}{llll}
\hline Entry & Ar & Product & Yield [\%] \\
\hline${ }_{8}[\mathrm{c}]$ & $4-\mathrm{ClC}_{6} \mathrm{H}_{4}$ &
\end{tabular}

${ }_{9}^{[c]} \quad 4-\mathrm{CF}_{3} \mathrm{C}_{6} \mathrm{H}_{4}$

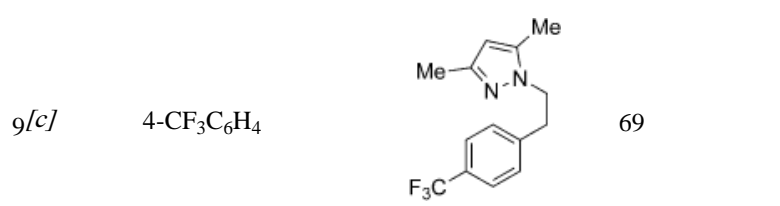

69

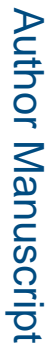
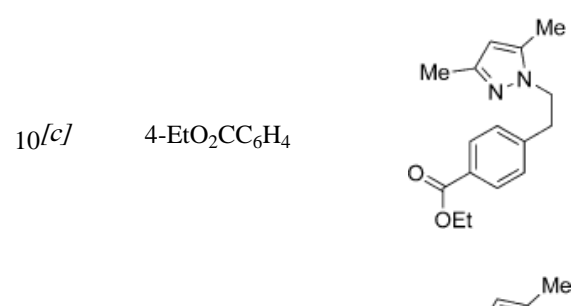

64

${ }_{11}[c] \quad 4-\mathrm{PhCOC}_{6} \mathrm{H}_{4}$

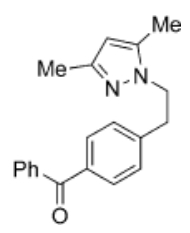

65

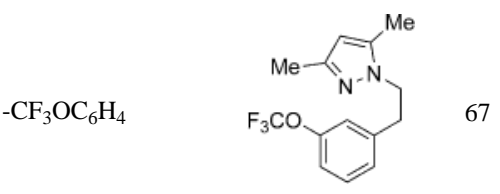

67

${ }_{12}[c] \quad 3-\mathrm{CF}_{3} \mathrm{OC}_{6} \mathrm{H}_{4}$

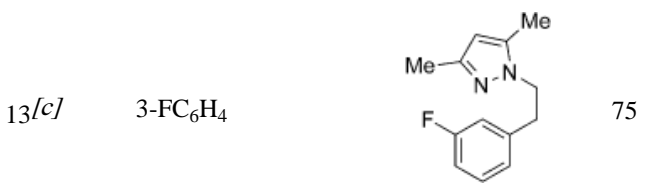

\footnotetext{
details.

${ }^{[b]}$ Temperature: $105^{\circ} \mathrm{C}$.

${ }^{[c]}$ Temperature: $120^{\circ} \mathrm{C}$.

${ }^{[d]}$ Temperature: $110^{\circ} \mathrm{C}$.

${ }^{[e]}$ Scale: $10 \mathrm{mmol}$.
}

${ }^{[a]}$ Pyrazole $1 \mathrm{mmol}$, hexafluoroisopropanol $0.75 \mathrm{~mL}, \mathrm{AcOH} 0.25 \mathrm{~mL}$. Yields of isolated product are given. See the Supporting information for 


\section{Table 3}

Reaction scope with respect to the alkylpyrazoles. ${ }^{[a]}$
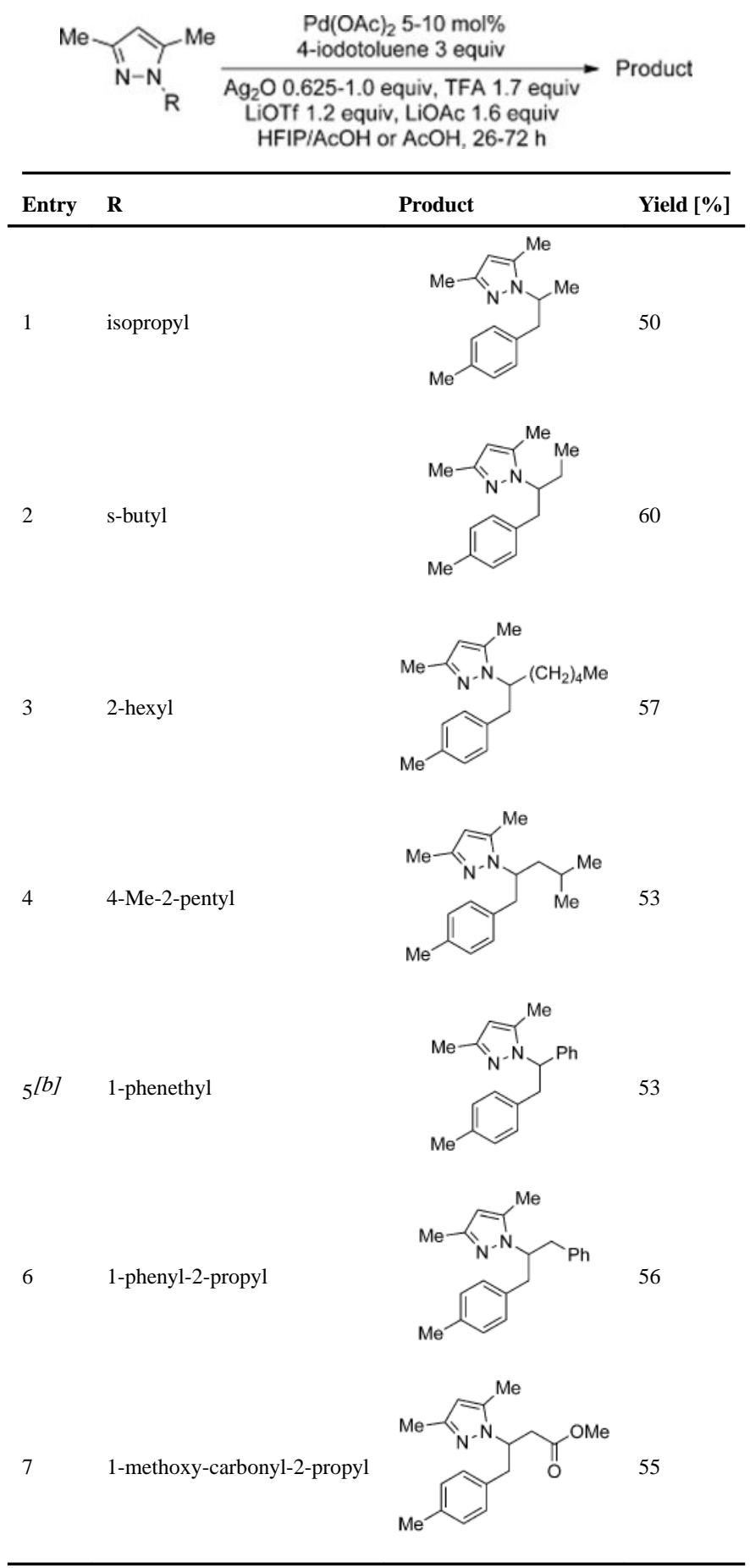

${ }^{[a]}$ Pyrazole $1 \mathrm{mmol}$, solvent: $1-2 \mathrm{~mL}$ of hexafluoroisopropanol/AcOH or $\mathrm{AcOH}$, temperature: $80-130^{\circ} \mathrm{C}$. Yields of isolated product are shown. See the Supporting information for details. 
${ }^{[b]}$ Purity: $91 \%$. 